\title{
The Quality of Liquidity Risk \\ Management of Bank Pembiayaan Rakyat Syariah (BPRS)/Islamic Rural Bank Using Liquidity Risk Management (LRM) Index Method
}

\section{Himmatul Kholidah, Nisful Laila and Imron Mawardi}

\begin{abstract}
Islamic Rural Bank (BPRS) is one of the financial institutions which is profit oriented and has a lot of risks. Liquidity is one of the main risks in Islamic Rural Bank. Islamic Rural Bank should maintain the effective and efficient pf assets, liabilities, and policy assessment in order to have the optimum quality of liquidity risk management. The research aims to study assessment on asset side, liability side and liquidity management policies that reflect the quality of liquidity risk management on Islamic Rural Bank in Sidoarjo. The research method used is quantitative approach. The data was collected by questionnaire for liquidity management manager of BPRS Baktimakmur Indah, BPRS Annisa Mukti and BPRS Unawi Barokah. The results shows that BPRS Baktimakmur Indah has an excellent quality of liquidity risk management, while BPRS Annisa mukti and BPRS Unawi Barokah have a good quality of liquidity risk management.
\end{abstract}

Keywords Islamic Rural Bank $\cdot$ Liquidity risk management Liquidity risk management (LRM) index

\section{Introduction}

One of the types of bank in Indonesia is Islamic Rural Bank (BPRS). According to Act No. 21 of 2008 concerning Islamic Banking, Islamic Rural Bank is defined as an Islamic bank that its activities do not give a service in terms of payment traffic. This is

\author{
H. Kholidah · N. Laila (凶) · I. Mawardi \\ Universitas Airlangga, Surabaya, Indonesia \\ e-mail: nisful.laila@ feb.unair.ac.id \\ H. Kholidah \\ e-mail: himmakh@gmail.com \\ I. Mawardi \\ e-mail: ron@gmail.com
}


Table 1 Total portion of BPRS financing in East Java Province (in million Rupiah)

\begin{tabular}{l|l|l}
\hline Financing & Total & Percentage $(\%)$ \\
\hline $\begin{array}{l}\text { Capital working and } \\
\text { investment }\end{array}$ & 547,984 & 48.76 \\
\hline Consumption & 575,826 & 51.23 \\
\hline Total & $1,123,810$ & 100 \\
\hline
\end{tabular}

Source Statistics Statistik Perbankan Syariah (SPS)/Islamic Banking, 2016

Table 2 Total assets of BPRS in Sidoarjo (in thousand Rupiah)

\begin{tabular}{l|l|l|l|l|l|l}
\hline BPRS & 2011 & 2012 & 2013 & 2014 & 2015 & 2016 \\
\hline $\begin{array}{l}\text { Baktimakmur } \\
\text { Indah }\end{array}$ & $47,371,911$ & $80,918,469$ & $108,165,347$ & $143,189,383$ & $150,358,342$ & $140,373,388$ \\
\hline Annisa Mukti & $5,163,457$ & $6,983,513$ & $8,258,994$ & $8,355,503$ & $9,527,753$ & $9,625,148$ \\
\hline Unawi Barokah & $1,974,256$ & $2,374,156$ & $3,232,357$ & $3,412,195$ & $3,396,491$ & $3,851,118$ \\
\hline
\end{tabular}

Source Publication of Bank Financial Reports in December 2016 (www.bi.go.id)

what causes Islamic Rural Bank is not allowed to offer wadiah giro and differentiate Islamic Rural Bank with Islamic banks and Islamic business units.

According to Outlook of Islamic Banking in 2014, Islamic Rural Bank (BPRS) as an intermediation institution gives its priority to provide financing to micro, small, and medium enterprises, especially in small areas such as village or regency. It is in line with the operational purpose from BPRS which is to improve social welfare in small areas so that it can also reach equitable economic welfare.

One of developed BPRSs is the BPRS in East Java Province. Soekarwo stated that East Java is ready to become a pilot project of Islamic economy in Indonesia. It is based on $90 \%$ East Java population which is moslem. There are about 6000 Islamic boarding schools which could be developed as a basis of Islamic banking and social culture that are very respectful to kyai (religious leader) in all things. It can be an asset in developing Islamic banking industry (Syariah.bisnis.com 2015).

The financing performance of BPRS in East Java in June 2015 report is that the portion of productive financing distribution-which includes working capital and investment-is bigger than the portion of consumption financing distribution. Tables 1 and 2 shows that the portion of working capital and investment financing is $51.23 \%$ of the total financing distributed. While the portion of consumption financing is $48.77 \%$ of the total financing distributed. The high portion of BPRS's productive financing in East Java shows that the public has started to trust BPRS as a business partner which is not only for fulfilling daily needs (consumption).

One of BPRSs in East Java is BPRS which is in Sidoarjo. Most of the population are Moslems and have reached $95 \%$ of the total population which amounts 1,603,136 people. Then, it has many Islamic boarding schools which are 25 (BPS). According to the publication of financial statement in Islamic Banking Statistics (SPS) on December 2016, there are three BPRSs in Sidoarjo, which are BPRS Annisa Mukti, BPRS Baktimakmur Indah and BPRS Unawi Barokah. The asset growth of these 
three BPRSs was continuously increasing from 2011 until 2016, and the total asset data was gained in December 2016.

BPRS as financial institution which is profit-oriented also has a lot of risks. It is because the risks are always attached to business activities. There must be a risk and it has been mentioned in Surah Lukman verse 34 which the meaning is: "Indeed, Allah [alone] has knowledge of the doomsday and sends down the rain and knows what is in the wombs. And no soul perceives what it will earn tomorrow, and no soul perceives in what land it will die. Indeed, Allah is The Knowing and The Aware".

The essence of this verse according to Department of Religion (2009:825) explains that human's knowledge is limited, and no one can ensure what is being done and what will happen tomorrow, as well as no one can perceive when and where he/she will die. It shows that the risk is an inseparable part of life.

One of the important risks in BPRS is liquidity risk. It relates to the function of the bank as a financial intermediary, so that the liquidity risk management is so important to BPRS. One of the risk managements faced by BPRS is liquidity risk management. BPRS has to consider the amount of liquidity appropriately, because if the liquidity amount is overwhelming, it could decrease this bank's efficiency which will affect bank's profitability, otherwise if the existing liquidity in bank is too small, then it will disturb operational daily needs. BPRS as financial intermediary must have an appropriate liquidity management, because on the one hand, BPRS must process its funds to earn revenue, and on the other hand, BPRS must provide its sufficient funds so that when there is a customer who withdraws his/her funds, BPRS has sufficient funds.

It also applies to liquidity risk management that it is not only limited to risk identification and mitigation, but also to design an appropriate liquidity risk management system by assessing liquidity risk management. It aims to find out the quality of liquidity risk management so that it could run effectively and efficiently. According to Ismal (2010), the assessment of liquidity risk management is performed by index of liquidity risk management in some managements, which are management on the side of asset, management on the side of liability, and management on the side of policy in liquidity management.

BPRS in a way of managing risk management has to maintain asset and liability managements and also create an appropriate policy so that liquidity risk management runs effectively and efficiently. That is why it is needed to do an assessment of liquidity risk management by using liquidity risk management index in BPRS Sidoarjo. Liquidity Risk Management (LRM) Index is an index that has been suggested by Ismal (2010) to measure a quality of liquidity risk management in Islamic Rural Banks in Indonesia. In this research, this liquidity risk management index will be adapted to the condition of BPRS.

Based on the background of the study above, the research problem is that "does the management on the side of asset, liability, and policy reflect on the quality of liquidity risk management in BPRS Sidoarjo?". 


\section{Theoretical Framework}

\section{Liquidity Risk Management}

In a term of liquidity management, the bank faces conflicting issues of keeping a sufficient supply of money to always be able to fulfill any withdrawal by the customer and provide sufficient funds to meet credit demand. In a term of bank, liquidity risk usually emerges in three things, which are: the way the bank manages primary reserve, the way the bank manages secondary reserve, and how the bank can manage daily funding. A good liquidity risk management can be performed by setting the financial position to deal with daily transaction. The intended transactions are withdrawal of deposit, disbursement of term deposit, and credit request.

\section{The Quality of Liquidity Risk Management in BPRS}

BPRS as an Islamic banking institution must be able to predict an accurate and appropriate liquidity management, because BPRS is directly related to micro, small, and medium enterprises activities where it becomes one of the real economic activities. If liquidity risk management cannot be done appropriately, then it will affect real economic balance and social welfare. In its practice, one of the main purposes of this liquidity management is to maintain the balance of management on the side of asset and liability.

Besides that, BPRS also has a role as a financial intermediary, supporter and facilitator, so that BPRS should position itself as a trusted institution for investors and business partners. That is why liquidity management in BPRS should be based on trust, conviction, and support of one another.

\section{The Quality of Liquidity Risk Management with LRM Index}

Theoretically (Ismal 2010), the assessment of liquidity risk management is done by liquidity risk management index in management of some sides, which are liability side and policy side in liquidity management. Liquidity risk management index is an index that has been suggested by Ismal (2010) to measure liquidity risk management.

All indexes in every aspect studied are separated in different questions with the aim of detecting bank actions on mitigation and prevention of liquidity risk in detail.

The assessment of the quality of liquidity risk management on asset, liability, policy sides could be categorized into four qualities, which are excellent, good, satisfactory, and poor. The total points on the assessment of each side are also categorized into four qualities, which are 100-75 points for excellent category, 74-50 for good category, 49-25 points for satisfactory category, and under 25 points for poor category (Table 3 ).

4. The Quality of Liquidity Risk Management with LRM Index in Management of Asset Side

The management on the side of asset, according to Ismal (2010) is done by analyzing liquidity risk management considering bank's effort in monitoring financing, 
Table 3 The assessment of the quality of liquidity risk management

\begin{tabular}{l|l|l|l|l|l}
\hline Assessment & Total points & Excellent & Good & Satisfactory & Poor \\
\hline Asset & 35 points & $26-35$ points & $17-25$ points & $8-16$ points & $\begin{array}{l}\text { Under 8 } \\
\text { points }\end{array}$ \\
\hline Liability & 35 points & $26-35$ points & $17-25$ points & $8-16$ points & $\begin{array}{l}\text { Under 8 } \\
\text { points }\end{array}$ \\
\hline Policy & 30 points & $22-30$ points & $15-21$ points & $7-14$ points & $\begin{array}{l}\text { Under 7 } \\
\text { points }\end{array}$ \\
\hline Total indexes & 100 points & $75-100$ points & $50-74$ points & $26-49$ points & $\begin{array}{l}\text { Under 25 } \\
\text { points }\end{array}$ \\
\hline
\end{tabular}

Source Ismal (2010)

arranging the appropriate allocation of financing, overcoming the failure of financing, overcoming bad economic condition, and dealing with the lack of liquidity. Monitoring, evaluation, and coordination of BPRS with its business partners reflect on the quality of BPRS management control (Greuning and Iqbal 2011).

5. The Quality of Liquidity Risk Management with LRM Index in Management of Liability Side

The management of liability side according to Ismal (2010), is done by evaluating and focusing on the bank's effort to manage an appropriate fund allocation, and build a good communication with customers relating to the way customers withdraw their funds which affects bank's liquidity, and also plan potential liquidity risk.

6. The Quality of Liquidity Risk Management with LRM Index in Management of Policy Side

The management of policy side in liquidity management focuses on the bank's effort in creating good liquidity management practice. In managing an appropriate liquidity management, Islamic bank should have a team or division that particularly handles liquidity risk, has quantitative model and insure all funds that have been collected before (Ismal 2010). In a practice of liquidity risk management, there should be an effort to maintain Islamic bank so that it could be in optimum liquidity level that both advantages and disadvantages of liquidity can be avoided. According to Ismal (2010), one way to do is to plan the appropriate Islamic bank finance arrangement.

\section{Research Method}

The approach used in this research is quantitative approach, while operational definitions of variables are explained as follows:

a. The management of asset side. The implementation of liquidity risk management on asset side in this research can be obtained by analyzing: 
1. The effort of BPRS in monitoring financing;

2. The effort of BPRS in managing an appropriate financing allocation;

3. The effort of BPRS in overcoming the failure of financing;

4. The effort of BPRS in overcoming bad economy condition;

5. The effort of BPRS in handling disadvantages of liquidity.

b. The management of liability side. The implementation of liquidity risk management on liability side in this research can be obtained by analyzing:

1. The effort of BPRS in evaluating and focusing on the bank's effort to manage an appropriate funds allocation;

2. The effort of BPRS in building a good communication with customers relating to the way they withdraw their funds which affects bank liquidity;

3. The effort of BPRS in planning potential liquidity risk.

c. The management of policy side. The implementation of liquidity risk management on policy side in this research by analyzing anything is related to the policy of BPRS in building a good liquidity management practice.

Data source used in this research consists of primary data and secondary data. The primary data was obtained directly from the location of the research by collecting data of filled questionnaire which had been arranged systematically. This questionnaire was addressed to the manager of liquidity management in BPRS. While the secondary data was obtained from related proofs: Central Bureau of Statistics, journal, internet, and the other relevant sources. The sample in this research is BPRS in Sidoarjo which are BPRS Baktimakmur Indah, BPRS Annisa Mukti, and BPRS Unawi Barokah.

In this research, the analysis technique used is analysis technique with Liquidity Risk Management (LRM) Index. It consists of three questions which are a question on asset side, liability side, and policy side in risk management. Every question from the management of asset, liability, and policy sides of risk management should have its respective index value. Then, the formula used in this research is:

Liquidity Risk Management (LRM) Index

$$
L=\sum_{\mathrm{t}=1}^{\mathrm{n}} A i+\sum_{\mathrm{t}=1}^{\mathrm{n}} B i+\sum_{\mathrm{t}=1}^{\mathrm{n}} C i
$$

where:

L Total indexes of the asset, liability, and policy sides management

$\mathrm{Ai}$ The management of asset side

Bi The management of liability side

$\mathrm{Ci}$ The management of policy side

$n$ Amount of indexes obtained from each management

$\mathrm{t}$ Duration in this research. 
Table 4 The quality of liquidity risk management in Islamic Rural Bank (BPRS) Sidoarjo with liquidity risk management (LRM) index

\begin{tabular}{l|l|l}
\hline BPRS & Total indexes & $\begin{array}{l}\text { The quality of liquidity risk } \\
\text { management }\end{array}$ \\
\hline Baktimakmur Indah & 75 points & Excellent \\
\hline Annisa Mukti & 62 points & Good \\
\hline Unawi Barokah & 64 points & Good \\
\hline
\end{tabular}

Source Writer, processed

Table 5 The quality of liquidity risk management in BPRS Sidoarjo in management of asset side with LRM index

\begin{tabular}{l|l|l}
\hline BPRS & Total indexes & $\begin{array}{l}\text { The quality of liquidity risk } \\
\text { management }\end{array}$ \\
\hline Baktimakmur Indah & 27 points & Excellent \\
\hline Annisa Mukti & 26 points & Excellent \\
\hline Unawi Barokah & 22 points & Good \\
\hline
\end{tabular}

Source Writer, processed

\section{Result and Discussion}

1. The Quality of Liquidity Risk Management of BPRS in Sidoarjo with Liquidity Risk Management (LRM)

The quality of liquidity risk management in BPRS Sidoarjo with Liquidity Risk Management (LRM) Index is shown in Table 4. The management of asset, liability and policy sides will reflect on the overall quality of liquidity risk management in BPRS Sidoarjo. The result of this research shows that each BPRS has made serious efforts to optimize the management of asset side, liability side, and policy side.

2. The Quality of Liquidity Risk Management in BPRS Sidoarjo in Management on Asset Side with LRM Index

The quality of liquidity risk management in BPRS Sidoarjo in management on asset side with LRM index is shown in Table 5.

In the practice of asset side management, all BPRSs in Sidoarjo put the reserve fund on another bank, because the reserve fund saving that is done by BPRS itself will have a high risk. These three BPRSs in Sidoarjo also put the reserve fund in Islamic banks, and there is only one BPRS which does not have the reserve fund in conventional bank, and that is BPRS Baktimakmur Indah. It is caused by the rule of Financial Services Authority i.e. if Islamic financial institution releases its fund in conventional bank, the interest will not be recognized as income, but as social fund. It will certainly damage BPRS, so that it would be better if BPRS puts its fund in Islamic bank which is able to provide additional income and help the development of the Islamic financial industry. 
Table 6 The quality of liquidity risk management in BPRS Sidoarjo with LRM index in management of liability side

\begin{tabular}{l|l|l}
\hline BPRS & Total indexes & $\begin{array}{l}\text { The quality of liquidity risk } \\
\text { management }\end{array}$ \\
\hline Baktimakmur Indah & 26 points & Excellent \\
\hline Annisa Mukti & 17 points & Good \\
\hline Unawi Barokah & 20 points & Good \\
\hline
\end{tabular}

Source Writer, processed

Each BPRS has a standard to determine beneficial financing. BPRS Baktimakmur Indah has equipped its marketing to analyze enterprises. BPRS Baktimakmur Indah provides financing for kinds of common ventures or enterprises that are operated in the respective branch of its area. BPRS Annisa Mukti will see the track record and track checking of prospective customer in Bank Indonesia to observe the customer behaviour from the previous record, and check the environment around customer's enterprise before distributing the financing. Monitoring, evaluation, and coordination of BPRS with its business partners reflect on the quality of control of BPRS management (Greuning and Zamir 2011).

The asset management of the three BPRSs in Sidoarjo has maximized the increase of BPRS' revenue through equity as a plan of the future more than the increase of its revenue based on debt. It relates to what Ismal (2010) has suggested that Islamic bank must utilize the funds for equity-based financing. The reason is that the equitybased financing can move the real sectors that are productive. It means that this financing is distributed for investment and working capital needs. Financing is the main component of BPRS productive asset in performing its function as a financial intermediary, so that the asset management is important to maximize revenue increase through equity. It happens because the revenue increase through debt will involve the other party so that it can increase the risk. The entire policies are performed to keep a balance in management of asset sides in BPRS Sidoarjo.

3. The Quality of Liquidity Risk Management in BPRS Sidoarjo with LRM Index in Management of Liability Side

The quality of liquidity risk management in BPRS Sidoarjo with LRM index in management of liability side is shown in Table 6.

The growth in every bank is strongly affected by the development of the ability to collect social funds, both small and large scales with adequate deposition period. The high short-term deposit in BPRS Sidoarjo does not become main incentive to liquidity risk problems. It is because BPRS has loyal consumers in each BPRS, so that many customers do deposit prolongation with automatic roll over (ARO), and it causes many short-term deposits do not disturb the balance of BPRS' liquidity.

The dominant deposit in all BPRSs Sidoarjo belongs to the public. The ownership of the deposit also influences the balance of BPRS's liquidity. The present government-owned deposit shows cooperative and communicative attitudes with 
Table 7 The quality of liquidity risk management in management of policy side in BPRS Sidoarjo with Liquidity Risk Management (LRM) Index

\begin{tabular}{l|l|l}
\hline BPRS & Total indexes & $\begin{array}{l}\text { The quality of liquidity risk } \\
\text { management }\end{array}$ \\
\hline Baktimakmur Indah & 22 points & Excellent \\
\hline Annisa Mukti & 19 points & Good \\
\hline Unawi Barokah & 22 points & Excellent \\
\hline
\end{tabular}

Source Writer, processed

Islamic banks, so that they do not worry about a sudden withdrawal which can disturb the balance of the liquidity. In another case, it is certainly different that the deposit is owned by the public personally but all BPRSs in Sidoarjo have loyal and communicative customers with them.

In the practice of liability side management, all BPRSs in Sidoarjo have planned and arranged their finance for the future by considering liquidity risk management which will prioritize more on putting the deposit in a long term. As Ismal (2010) has suggested that the planning of Islamic bank finance related to liquidity risk management prioritizes more on planning the deposit in a long term, choosing deposit instrument which is in accordance with the condition and need of Islamic bank, and matching the deposit funds with another bank as a reference of financing and last option which is to cooperate with another banks. These all policies are performed to keep the balance of liability side management in BPRS Sidoarjo.

4. The Quality of Liquidity Risk Management in BPRS Sidoarjo with LRM Index in Management of Policy Side

The quality of liquidity risk management in management of policy side in BPRS Sidoarjo with Liquidity Risk Management (LRM) Index is shown in Table 7.

In the practice of policy side management, all BPRSs in Sidoarjo has a model qualitatively to keep the liquidity balance from each BPRS. A quantitative model which is owned by BPRS is in the form of a special system that is owned by respective BPRS. This system functions to monitor funds development from BPRS, both are collected and received by BPRS. The quantitative model is also one of the efforts of BPRS to build the optimal practice of liquidity management.

When the case of failure with business partners happens, all BPRSs will switch to profit reserve owned. It is because Islamic bank is a profit-oriented Islamic finance institution. The profit is not only a matter of importance from the owner, but also the importance to develop operational venture or enterprise from the Islamic banks so that they can keep operating.

When liquidity run happens, BPRS Baktimakmur Indah and BPRS Unawi Barokah prioritize more to release deposit that has been in another bank, while BPRS Annisa Mukti prioritizes more to evaluate the planning between the due date of financing and the due-date of deposit. When liquidity run is not applicable anymore to do evaluation and planning, concrete step must be done, which is releasing the 
deposit that is in another bank. All these policies are performed to keep the balance of policy side management in BPRS Sidoarjo.

\section{Recommendation}

1. To BPRS in Sidoarjo, especially BPRS Baktimakmur Indah, it is important to mantain the performance of asset, liability, and policy sides management, so that the quality of liquidity risk management can reach excellent category. While BPRS Annisa Mukti needs to improve the performance of liability and policy sides management, so that the quality of liquidity risk management can also reach excellent category. The last one is BPRS Unawi Barokah that needs to improve the performance of asset and liability sides management, so that the quality of liquidity risk management can reach excellent category. Besides that, BPRS Annisa Mukti and Unawi Barokah that still cooperate with conventional bank, hopefully can involve Islamic banks only in operational term in the future. It is just for avoiding riba and supporting the progress of Islamic finance institutions in Indonesia.

2. To the government, it is important to give some solutions to BPRS when it faces advantages and disadvantages of liquidity. Some solutions are by actualizing APEX BPR and especially involving all parties i.e. the academics, practitioners, and religion leaders (ulama) to participate in socializing the performance of BPRS to the public.

\section{References}

Greuning, H., Iqbal, Z.: Analisis Risiko Perbankan Syariah. Salemba Empat (2011)

Ismal, R.: Assessment of liquidity management in Islamic banking industry. Int. J. Islam. Middle East. Financ. Manage. 3, 147-167 (2010)

Syariah - Berita Terbaru tentang Asuransi, Bank, Pasar Modal, Jakarta Islamic Index dan Ekonomi Syariah. http://syariah.bisnis.com/

Undang-undang Nomor 21 Tahun 2008 Tentang Perbankan Syariah. https://www.ojk.go.id/ $\mathrm{id} / \mathrm{kanal} /$ perbankan/regulasi/undang-undang/Pages/undang-undang-nomor-21-tahun-2008tentang-perbankan-syariah.aspx 